\title{
RESPON MASYARAKAT TERHADAP MTS ALKHAIRAT PUSAT PALU
}

\author{
Community Response to The Center \\ of Madrasah Tsanawiyah (MTs) Alkhairat in Palu
}

\author{
Oleh: Abdul Rahman Arsyad* \\ *Peneliti pada Balai Penelitian dan Pengembangan Agama Makassar \\ Kantor: Jalan AP. Pettarani No. 72 Makassar \\ E-mail: rahmanarsyad70@yahoo.com
}

\begin{abstract}
Abstrak
Penelitian ini bertujuan untuk mengungkap respon masyarakat terhadap madrasah terakreditasi pada MTs Alkhairat Pusat Palu. Hal ini merupakan bagian dari penelitian tentang informasi madrasah akreditasi, dengan melihat bagaimana tingkat pengetahuan, penilaian, dan; partisipasi masyarakat ..".7" MTs Alkhairat Pusat Palu. Penelitian ini menggunakan metode kuantitatif dalam analisis data selain angket/quesioner akan dianalisis secara deskriptif kuantitatif untuk mengetahui kecendrungan dan respon masyarakat terhadap madrasah terakreditasi. Adapun datayang diperoleh melalui wawancara, audi pustaka, dan dokumentasi. Hasil analisis disajikan lewat label dan grafik bagi data kuantitas dan naratif bagi data kualitas. Hasil penelitian ini menunjukkan bahwa tingkat pengetahuan dan penilaian masyarakat terhadap MTs Alkhairat Pusat Palu terkategori tinggi dengan nilai rata-rata $r=3.3$, sedangkan partisipasi masyarakat terkategori cukup tinggi dengan nilai rata-rata $r=2.3$.
\end{abstract}

Rata Kunci: respon masyarakat, madrasah akreditasai.

\section{Abstract}

This research intended to reveal the public response to an accredited Madrasah like in Central of Madrasah Tsanawiah/MTs (junior high school) Alkhairat in Palu city. This is a part of research on information of Madrasah accreditation, to see how the level of knowledge, assessment, and community participation to terof MTs Alkhairat in Palu. This research apply qualitative methods in data analysis in addition to the questionnaire that will analyzed descriptively and quantitatively to determine the tendency and public response to an accredited Madrasah. The data obtained by interview, literature study, and documentation. The

is of the analysis are presented through tables and graphs for data quantity and quality of the narrative for qualitative the data. From this research found that the level of public knowledge and assessment to the Central of MTs Alkhairat Palu, High categorized by the average value of $r=3.3$, while community participation is high enough categorized by the average value ofr $=2.3$.

key Words: community response, madrasah accreditation

\section{ENDA HUL UA N}

$\mathrm{P}$

da Peraturan Pemerintah No. 19 Tahun 2005 Pasal 2 ayat (2) tentang Standar Nasional Pendidikan menyatakan bahwa penjaminan dan . alian mutu pendidikan perlu dilakukan tiga pro*rrtifikasi.'

erintegrasi yaitu evaluasi, akreditasi dan

Penegasan tentang pentingnya standar pendidikan $\mathrm{j}^{\wedge}$ rsebut dapat dilihat pada Undang-Undang Nomor Ti'r.un 2003 tentang Sistem Pendidikan Nasional -::knas), B AB XVI Bagian Kedua Pasal 60, tentang
Akreditasi yang berbunyi sebagai berikut: (1) Akreditasi dilakukan untuk menentukan kelayakan program dan satuan pendidikan padajalur pendidikan formal dan nonformal pada setiap jenjang dan jenis pendidikan.

Berkaitan dengan hal tersebut, Pemerintah telah menetapkan Badan Akreditasi Nasional Sekolah/ Madrasah (BAN-S/M) dengan Peraturan Mendiknas Nomor 29 Tahun 2005. BAN-S/M adalah badan evaluasi mandiri yang menetapkan kelayakan program dan/atau satuan pendidikan jenjang pendidikan dasar dan menengah jalur formal dengan mengacu pada

〜:tp: septiavuambarsari.blogspot.com/2010/05/definisi-akreditasi-sekolah madrasah html. 
standar nasional pendidikan. Sebagai iftstitusi yang bersifat mandiri di bawah dan bertanggung jawab kepada Mendiknas, BAN-S/M bertugas merumuskan kebijakan operasional, melakukan sosialisasi kebijakan, dan melaksanakan akreditasi sekolah/madrasah. Dalam melaksanakan akreditasi sekolah/ madrasah, BAN-S/M dibantu oleh Badan Akreditasi Provinsi Sekolah/Madrasah (BAP-S/M) yang dibentuk oleh gubernur, sesuai Peraturan Pemerintah Nomor 19 Tahun 2005 tentang Standar Nasional Pendidikan, khususnya Pasal 87 ayat (2).

Penelitian yang dilakukan oleh Bambang Budi Rahajo di Kabupaten Banyumas Jatim tentang "dampak kebijakan akreditasi sekolah dan sertifikasi guru terhadap peningkatan mutu pendidikan." Khusus pada akreditasi sekolah, temuan studi menunjukkan bahwa semua sekolah yang menjadi responden dalam studi ini menyatakan kesiapannya dalam menghadapi akreditasi sekolah. $94 \%$ responden sekolah menyatakan kesiapannya pada komponen kurikulum, 96.6\% sekolah menyatakan siap terkait komponen proses pembelajaran, $89.7 \%$ menyatakan kesiapannya pada komponen kompetensi lulusan, $88.9 \%$ menyangkut kesiapan pada komponen tenaga pendidik dan tenaga kependidikan, $75.2 \%$ menyangkut sarana dan prasarana, $97.2 \%$ responden sekolah menyatakan kesiapannya pada komponen pengelolaan sekolah, $76.1 \%$ kesiapan pada komponen pembiayaan sekolah dan $84.6 \%$ responden sekolah menyatakan kesiapannya pada komponen sistem penilaian. Ditemukan adanya dampak positif dari akreditasi sekolah terhadap peningkatan sekolah ditelaah dari peningkatan dari komponen-komponen: (1) kurikulum dan pembelajaran, (2) administrasi dan manajemen sekolah, (3) organisasi kelembagaan, (4) sarana dan prasarana, (5) ketenagaan, (6) pembiayaan, (7) peserta didik, (8) peran serta masyarakat, dan (9) lingkungan budaya sekolah. ${ }^{3}$

Selain itu penelitian yang dilakukan oleh Srihani di SD Negeri Donohudan 3 Kecamatan Ngemplak Kabupaten Boyolali yang menggambarkan proses akresitasi telah berjalan sesuai pedoman akreditasi dan
SD tersebut memperoleh hasil nilai/ score 80 dengan status terakreditasi B (Baik). Dampak dari pelaksanaan akreditasi menunjukkan adanya peningkatan mutu yang diantaranya dibuktikan dengan banyaknya siswa baru yang berasal dari TK, mutu proses dibuktikan dengan meningkatnya persentase kehadiran siswa, mutu output dibuktikan dari menurunnya persentase angka kelulusannya. Mutu guru dibuktikan dari meningkatkan angka kehadiran kedisiplinan dari tertib administrasi. Mutu sarana dan prasarana dibuktikan dengan meningkatnya kelengkapan sarana sekolah, dan mutu biaya dibuktikan dengan meningkatnya bantuan dari partisipasi masyarakat. ${ }^{4}$

Akreditasi sekolah jugatampak berdampak terhadap peningkatan prestasi siswa. Penelitian yang dilakukan oleh Slamet Umi Nur Barokah 2005 tujuh SMA se-Kabupaten Banjarnegara menujukkan bahwa besarnya pengaruh akreditasi sekolah terhadap prestasi belajar mata pelajaran ekonomi sebesar $94 \%$ dengan

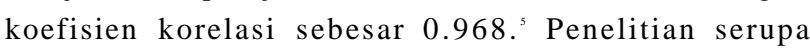
dilakukan oleh Anik Hidajati yang mengamati peran kepemimpinan Kepala Sekolah sehingga SMP Negeri 4 Karanganyar memperoleh peringkat akreditasi A pada tahun 2009. Penelitian menunjukkan bahwa pola kepemimpinan yang diterapkan oleh kepala yang demokratis dengan gaya dan tipe kepemimpinan yang situasional, kadang-kadang menerapkan tipe delegatif, kadang partisipatif dan kadang menerapkan konsultatif mengambil andil dalam perolehan peringkat sertifikasi. ${ }^{\circ}$

Adapun masalah penelitian ini adalah 1) Bagaimana tingkat pengetahuan masyarakat terhadap kualitas madrasah terakreditasi? 2) Bagaimana tingkat sikap masyarakat terhadap kualitas madrasah terakreditasi? 3) Bagaimana tingkat partisipasi/ keterlibatan masyarakat terhadap peningkatan kualitas madrasah terakreditasi?

\section{Metode Penelitian}

Penelitian ini mengambil lokasi di Kota Palu di Sulawesi Tengah. Penelitian ini menggunakan jenis penelitian deskriptif kuantitatif. Sumber pengumpulan

-Badan Akreditasi Nasional Sekolah/Madrasah. 2009. Kebijakan dan Pedoman Akreditasi Sekolah/Madrasah. Profesional, Terpercaya dan Terbuka. Jakarta: BAN, h. ii)^

Bambang Budi Raharjo, Dampak Kebijakan Akreditasi Sekolah dan Sertifikasi Guru terhadap Peningkatan Mutu Pendidikan di Kabupaten Banyumas, Propinsi Jawa Tengah. [Experiment], http://eprints.ui.ac.id/78638/

Srihani. 2006. Analisis Dampak Akreditasi Sekolah Dalam Peningkatan Mutu Pendidikan (Studi Kasus Di SD Negeri Donohudan 3 Kecamatan Ngemplak Kabupaten Boyolali). Thesis thesis, Universitas Muhammadiyah Surakarta, (http://etd.eprints.ums.ac.id/6856/)

Slamet Umi Nur Barokah. 2005. Pengaruh Akreditasi Sekolah dan Persepsi Guru mengenai Supervisi Kepala Sekolah Terhadap Prestasi Belajar Siswa. Jurusan Pendidikan Ekonomi Akuntansi. Fakultas Ilmu Sosial Universitas Negeri Semarang. (http://digilib.unnes.ac.id/ $\mathrm{gsdl} / \mathrm{collect/skripsi/}$ archives/HASH5bl3.dir/doc.pdf)

'Anik Hidajati. 2009. Peran Kepala Sekolah dalam Perolehan Status Akreditasi Sekolah di SMP Negeri 4 Karanganyar. Tesis. Surakarta Program Studi Teknologi Pendidikan, Program Pascasarjana, Universitas Sebelas Maret, Desember. 2009. ( http://pasca.uns.ac.id/'p=384) 
orang tua siswa dan masyarakat yang berisckitar madrasah dengan menggunakan Penarikan sampel dilakukan dengan dua porposive dan random. Penarikan secara porposive dilakukan pada penentuan

dan lokasi masyarakat yang dijadikan mengacu pada madrasah ter-

Dan penarikan sampel dari orang tua lakukan berdasarkan daftar siswa yang ada kelas di madrasah terakreditasi. Analisis lelalui angkat/quesioner akan dianalisis deskritif kuantitatif dengan menggunakan

isis pemusatan Sedangkan data atau ing diperoleh dengan menggunakan studi pustaka dan dokumentasi akan secara kualitatif dengan proses klasifikasi, kemudian penarikan kesimpulan berupa litian. Hasil analisis disajikan dengan an tabel dan grafik bagi data kuantitas if bagi data kualitas.

\section{Pustaka}

\section{n Tentang Teori Respon}

- . -r 7 berasal dari kata response, yang berarti balasan atau tanggapan (reaction). Dalam 3esar Bahasa Indonesia edisi ketiga dijelaskan respon adalah berupa tanggapan, reaksi dan Dalam pembahasan teori respon tidak lepas --:7.::>an proses teori komunikasi, karena merupakan timbal balik dari apa yang nikasikan terhadap orang-orang yang terlibat unikasi. Respon merupakan salah satu proses komunikasi.

hlihat dari bentuk respon terhadap stimulus ini, iperilaku dapat dibedakan menjadi duayaitu: 1) tertutup adalah respon seseorang terhadap dalam bentuk terselubung atau tertutup (coRespon atau reaksi terhadap stimulus ini masih :'"i:is pada perhatian, persepsi, pengetahuan/ in. dan sikap yang terjadi belum bisa diamati ijelas oleh orang lain. 2) Perilaku terbuka adalah seseorang terhadap stimulus dalam bentuk can nyata atau terbuka. Respon terhadap terhadap s tersebut sudah jelas dalam bentuk tindakan praktek (practice).
Perilaku adalah suatu kegiatan atau aktifitas organisme (makhluk hidup) yang bersangkutan. Oleh sebab itu, dari sudut pandang biologis semua makhluk hidup mulai dari tumbuh-tumbuhan, binatang sampai dengan manusia itu berperilaku, karena mereka mempunyai aktifitas masing-masing. Sehingga yang dimaksud perilaku manusia, pada hakikatnya adalah tindakan atau aktifitas manusia itu sendiri yang mempunyai bentangan yang sangat luas antara lain: berjalan, berbicara, tertawa, bekerja, kuliah, menulis, membaca dan sebagainya. Dari uraian di atas dapat disimpulkan bahwa yang dimaksud perilaku (manusia) adalah semua kegiatan atau aktifitas manusia, baik yang dapat diamati langsung maupun yang tidak dapat diamati pihak luar.

Berdasarkan teori yang dikemukan oleh Stave M Caffe, respon dibagi menjadi tiga bagian, yaitu: a) Kognitif, yaitu respon yang berkaitan erat dengan pengetahuan, keterampilan dan informasi seseorang mengenai sesuatu. Respon ini timbul apabila adanya perubahan terhadap yang dipahami atau dipersepsi oleh khalayak. b) Afektif, yaitu respon yang berhubungan dengan emosi, sikap, dan penilaian seseorang terhadap sesuatu. c) Konatif, yaitu respon yang berhubungan dengan prilaku nyata yang meliputi tindakan dan perbuatan.

David Aaker memiliki asumsi dasar bahwa khalayak secara aktif terlibat dalam proses penerimaan informasi dengan cara mengevaluasi informasi yang diterima berdasarkan pengetahuan dan sikap yang dimiliki sebelumnya, yang akhirnya mengarah pada perubahan sikap. Teori ini mengasumsikan bahwa ketika informasi mengubah tingkah laku secara kuat, hal ini disebabkan khalayak (individu) mempelajari isi pesan yatlg dilihatnya yang kemudian akan mengarahkan ke perubahan tingkah laku terhadap obyek respon.

Proses perubahan sikap komunikan dimulai ketika informasi (ed exposure) menyentuh kesadaran, pemahaman dan pengatahuan komunikan (kognitif response) yang selanjutnya menimbulkan perubahan prilaku individu. Aaker menjelaskan bahwa yang paling menentukan tingkah laku adalah adanya pengetahuan dan sikap yang sebelumnya telah dimiliki oleh individu ketika dirinya menghadapi obyek respon."

•.r «uw.infoskripsi.com/ Free-Resource Konsep-Perilaku-Pengertian-PeriIaku-Bentuk-PeriIaku-dan-Domain-Perilaku.html - wwvvhasanismailr.blogspot.com/2009/06/pengertian

Badruzzaman dan Mukjizatullah. 2009. Respon Masyarakat Terhadap Madrasah Diniyah. Makassar: Laporan Penelitian Balai $s-i$ Agama, h. 8-9. 


\section{Akreditasi Sekolah/Madrasah}

Akreditasi sekolah/madrasah adalah proses penilaian secara komprehensifterhadap kelayakan dan kinerja satuan dan/atau program pendidikan, yang dilakukan sebagai bentuk akuntabilitas publik.

Di dalam proses akreditasi, sebuah sekolah/ madrasah dievaluasi dalam kaitannya dengan arah dan tujuannya, serta didasarkan kepada keseluruhan kondisi sekolah/madrasah sebagai sebuah institusi belajar.

$\mathrm{V}$

Akreditasi sekolah/madrasah bertujuan untuk memberikan informasi tentang kelayakan sekolah/ madrasah atau program yang dilaksanakannya berdasarkan StandarNasional Pendidikan, memberikan pengakuan peringkat kelayakan, memberikan rekomendasi tentang penjaminan mutu pendidikan kepada program dan atau satuan pendidikan yang diakreditasi dan pihak terkait.

Manfaat hasil akreditasi sekolah/madrasah sebagai berikut: membantu sekolah/madrasah dalam menentukan dan mempermudah kepindahan peserta didik dari suatu sekolah ke sekolah lain, pertukaran guru, dan kerjasama yang saling menguntungkan, membantu mengidentiflkasi sekolah/madrasah dan program dalam rangka pemberian bantuan pemerintah, investasi dana swasta dan donatur atau bentuk bantuan lainnya, Acuan dalam upaya peningkatan mutu sekolah/madrasah dan rencana pengembangan sekolah/madrasah umpan balik sebagai usaha pemberdayaan dan pengembangan kinerja warga sekolah/madrasah dalam rangka menerapkan visi, misi, tujuan, sasaran, strategi, dan program sekolah/madrasah motivator agar sekolah/ madrasah terus meningkatkan mutu pendidikan secara bertahap, terencana, dan kompetitif baik di tingkat kabupaten/kota, provinsi, nasional bahkan regional dan internasional, bahan informasi bagi sekolah/ madrasah sebagai masyarakat belajar untuk meningkatkan dukungan dari pemerintah, masyarakat, maupun sektor swasta dalam hal profesionalisme, moral, tenaga, dan dana.

Akreditasi sekolah mencakup delapan komponen dalam Standar Nasional Pendidikan: Standar Isi (Permendiknas No. 22/2006), Standar Proses (Permendiknas No. 41/2007), Standar Kompetensi Lulusan (Permendiknas No. 23/2006), Standar Pendidik dan Tenaga Kependidikan (Permendiknas No. 13/2007 tentang Kepala Sekolah, Permendiknas No. 16/2007 tentang Guru, Permendiknas No. 24/2008 tentang Tenaga Administrasi), Standar Sarana dan Prasarana (Permendiknas 24/2007), Standar Pengelolaan (Permendiknas No. 19/2007), Standar Pembiayaan (Peraturan Pemerintah. 48/2008), dan Standar Penilaian Pendidikan. (Permendiknas 20/ 2007).

Sesuai dengan Keputusan Menteri Pendidikan Nasional Nomor 087/U/2002 tanggal 14 Juni 2002 tentang Akreditasi Sekolah/Madrasah yang menjadi bahan penilaian adalah: kurikulum dan proses pembelajaran, administrasi dan manajemen sekolah /madrasah, organisasi dan kelembagaan sekolah/ madrasah, sarana dan prasarana, ketenagaan, pembiayaan, peserta didik, peran serta masyarakat, dan lingkungan dan budaya sekolah/madrasah.

\section{HASIL DAN PEMBAHASAN}

\section{Profil Madrasah Tsanawiyah Alkhairat Pusat Palu}

MTs Alkhairat Pusat Palu berdiri pada tahun 1975 oleh KH. Habib Idrus Bin Salim Aldjufri yang disebut dengan Guru Tua. Dalam perkembangannya Madrasah Aliyah Alkhairat Pusat Palu dan MTs Alkhairat Pusat Palu terpisah sejak tahun 1982. MTs Alkhairat Pusat Palu dipimpin oleh KH. Bahrain Tayyib 1975-1978, Drs. H. AliAbd. Rauf Sulaiman 1978-1981, H. Suaib Bandera, BA 1981 1988, Drs. Ali Karim 1988-1990, Drs. Muchlis Saddan 1990-1992, KH. Husen Kambayan 1992 1995, H. Ahmad Aldjufri, BA 1995-2003, kemudian Dra. Hj. Saihun Aldjufri tahun 2003 sampai sekarang.

Visi dan Misi, "Membentuk generasi unggul yang memiliki ilmu pengetahuan, keterampilan dan berakhlakul karimah." Yakni, Melaksanakan proses belajar mengajar yang bermutu, efektif dan efesien, meningkatkan harkat dan kualitas sumber daya manusia, meningkatkan kinerja profesionalisme guru dan pegawai, melaksanakan kegiatan keagamaan secara konsisten, mengelola lingkungan yang sehat, asri dan nyaman, melaksanakan kegiatan ekstra kurikuleryang beragam sesuai bakat dan minat siswa, melaksanakan keterampilan siswa (life Skill) untuk mengembangkan potensi diri dalam kehidupan bermasyarakat. 
man Masyarakat Terhadap Madrasah Henkreditasi

\section{"_kat Pengetahuan Responden Terhadap rus Akreditasi}

Grafik 1.

tahuan Responden Terhadap Status Akreditasi

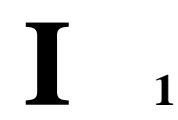

: ahuan responden terhadap status Akreditasi MTS Alkhairat Pusat Palu. Hal ini Jiapat dibuktikan dari hasil analisis terhadap :aan responden. Terdapat 83.4 persen den menyatakan cukup tahu terhadap sta-b tersebut dan 16.6 persen menyatakan kurang

ominan masyarat/orang tua siswa $": \sim$ ihami tentang status akreditasi pada MTS - • $i$ rat Pusat Palu.

Grafik 2.

:.i2etahuan Responden Terhadap Kualitas MTS Alkahirat

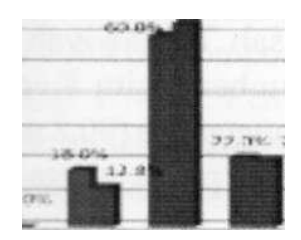

Tingkat pengetahuan responden terhadap kualitas 7 Alkhairat. Tingkat pengetahuan orang tua siswa 12" : mengetahui dan $18 \%$ menyatakan kurang tahu

- -an masyarakat $87,2 \%$ mengetahui dan $12,8 \%$ - r-. \atakan kurang tahu terhadap kualitas MTS

rat Pusat Palu. Maka dapat disimpulkan bahwa irisyarakat lebih memahami kualitas madrasah : : anding orang tua siswa itu sendiri.
2. Komponen Akreditasi MTS Alkhairat Pusat Palu.

\section{Grafik 3.}

Komponen Akreditasi MTS Alkhairat Pusat Palu

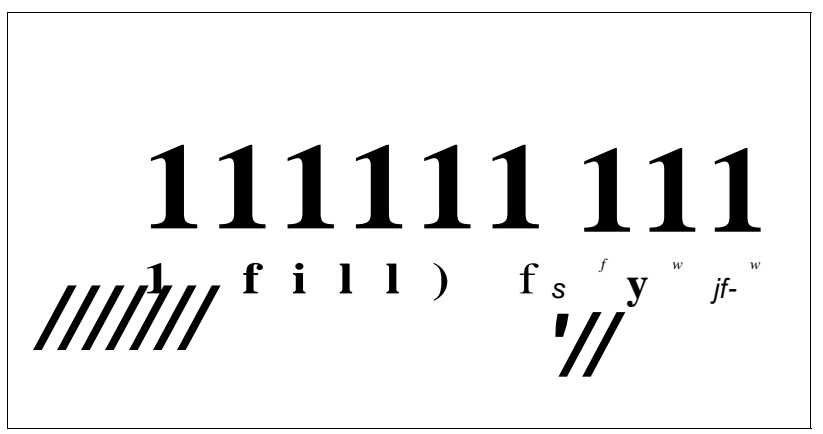

Keterangan:

$\begin{array}{ll}0,0-1,0 & =\text { Sangat Rendah } \\ 1,1-2,0 & =\text { Rendah } \\ 2,1-3,0 & =\text { Cukup Tinggi } \\ 3,1-4,0 & =\text { Tinggi } \\ 4,1-5,0 & =\text { Sangat Tinggi }\end{array}$

Setelah dilakukan analisis pemusatan terhadap item-item jawaban responden maka tergambar bahwa tingkat pengetahuan responden terhadap delapan komponen berkaitan dengan Madrasah Tsanawiyah Alkhairat Pusat Palu terkategorikan tinggi. Delapan item komponen kualitas yang ditelusuri dalam penelitian ini, cendrung berada pada kategori tersebut, kecuali ada pengetahuan responden terhadap item kualitas pengelolaan, yaitu berada pada kategori cukup tinggi. Berikut diuraikan kedelapan item komponen akreditasi tersebut:

a. Tingkat pengetahuan responden terhadap kualitas KTSP.

Pengetahuan responden terhadap kualitas kurikulum MTS Alkhairat Pusat Palu kategori tinggi (rata-rata skor 3.1), hal ini dapat dilihat pada distribusi jawaban yaitu, kurikulum MTS Alkhairat Pusat Palu $80.4 \%$ menyatakan mengetahui, dan $19.6 \%$ menyatakan kurang tahu. Dominan masyarakat memahami hal tersebut, karena mereka melihat dari komponen mata pelajaran MTS Alkhairat Pusat Palu sudah efektif dalam penerapannya terhadap siswa.

b. Tingkat pengetahuan responden terhadap kualitas proses pembelajaran.

Proses pembelajaran MTS Alkhairat Pusat Palu terkategori tinggi (rata-rata skor 3.4). Hal ini 
dibuktikan pada distribusi jawaban responden terhadap item kualitas proses pembelajaran. Sejumlah 91,8\% menyatakan mengetahui, dan $8.2 \%$ menyatakan kurang tahu. Kualitas pembelajaran terlihat baik, dikarenakan hasil/nilai siswa yang dijadikan sebagai indikator dan alokasi waktu jam pelajaran terlihat efisien.

c. Tingkat pengetahuan responden terhadap kualitas kepala madrasah.

Pengetahuan responden terhadap kualitas kepala madrasah pada MTS Alkhairat Pusat Palu terkategori tinggi (rata-rata skor 3.3). Terdapat jumlah 82,5\% menyatakan mengetahui dan $17,5 \%$ menyatakan kurang tahu. Masyarakat melihat dari terobosan dan kebijakan yang dilakukan oleh seorang Kamad.

d. Tingkat pengetahuan responden terhadap kualitas guru.

Pengetahuan responden terhadap kualitas guru terkategori tinggi (rata-rata skor 3.6). Tingkat tersebut dapat dibuktikan pada distribusi jawaban responden terehadap item pertanyaan tersebut, $91.7 \%$ menyatakan mengetahui, dan $8.3 \%$ menyatakan kurang tahu. Masyarakat cendrung melihat pada kompetensi personalnya (kematangan pribadi) dan latar belakang pendidikan yang rata-rata sarjana.

e. Tingkat pengetahuan responden terhadap kual itas tenaga administrasi.

Pengetahuan responden terhadap kualitas tenaga administrasi terkategori cukup tinggi (rata-rata skor 2.9). Tingkat tersebut dapat dibuktikan pada distribusi jawaban responden terehadap item pertanyaan tersebut, $79.1 \%$ menyatakan mengetahui, dan 20,9\% menyatakan kurang tahu. Terlihat dalam hal pelayanan yang dirasakan oleh masyarakat sangat bersahabat.

f. Tingkat pengetahuan responden terhadap kualitas pengelola.

Pengetahuan responden terhadap kualitas pengelola terkategori cukup tinggi (rata-rata skor 2.8). Tingkat tersebut dapat dibuktikan pada distribusi jawaban responden terehadap item pertanyaan tersebut, $61.8 \%$ menyatakan mengetahui, dan $38.2 \%$ menyatakan kurang tahu. Karena kompetensi profesional tenaga pendidik dan kependidikan dapat dirasakan oleh masyarakat/orang tua siswa.

g. Tingkat pengetahuan responden terhadap kualitas sarana dan prasarana.
Pengetahuan responden terhadap kualitas sarana dan prasarana terkategori tinggi (rata-rata skor 3.1). Tingkat tersebut dapat dibuktikan pada distribusi jawaban responden terhadap item pertanyaan tersebut, $85.6 \%$ menyatakan mengetahui, dan $14.4 \%$ menyatakan kurang tahu. Kelengkapan ruang belajar terlihat cukup memadai ditambah dengan lingkungan yang sangat bersahabat.

h. Tingkat pengetahuan responden terhadap kualitas pembiayaan.

Pengetahuan responden terhadap kualitas pembiayaan terkategori tinggi (rata-rata skor 3.2). Tingkat tersebut dapat dibuktikan pada distribusi jawaban responden terehadap item pertanyaan tersebut, $75.2 \%$ menyatakan mengetahui, dan $24.8 \%$ menyatakan kurang tahu. Selalu ada kemudahan atau kebijakan dari pihak MTS Alkhairat terhadap siswa.

i. Tingkat pengetahuan responden terhadap kualitas evaluasi.

Pengetahuan responden terhadap kualitas evaluasi terkategori cukup tinggi (rata-rata skor 2.7). Tingkat tersebut dapat dibuktikan pada distribusi jawaban responden terehadap item pertanyaan tersebut, $58.7 \%$ menyatakan mengetahui, dan $41.3 \%$ menyatakan kurang tahu. Tenaga pendidik dan kependidikan konsfeten terhadap misi dan visi MTS Alkhairat Pusat Palu.

\section{Sumber Pengetahuan Responden}

Tampak bahwa dominan responden mengetahui status akreditasi Madrasah Tsanawiyah Alkhairat Pusat Palu pada dua sumber, yaitu Kepala/Guru/ Administrasi dan keluarga/tetangga (90.8 persen). Hal ini mengindikasikan bahwa peran warga Madrasah Tsanawiyah Alkhairat Pusat Palu dalam mensosialisasikan status akreditasi mendominasi kegiatankegiatan instansi lain termasuk B AN S/M.

Grafik 4.

Tingkat pengetahuan responden dalam memperoleh informasi.

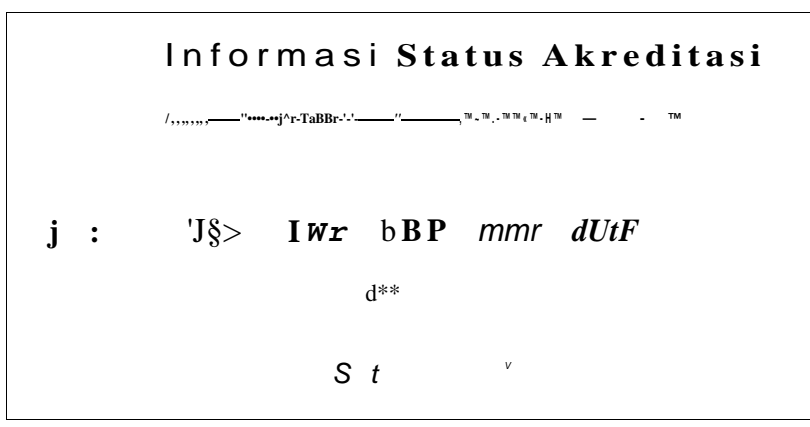

Jurnal "Al-Qalam" Volume 1 Nomor 17 Januari - Juni 2011 
Sakreditasi Madrasah Tsanawiyah Alkhairat Palu. Tingkat tersebut dapat dibuktikan pada jaw aban responden terehadap item pertanyaan $51.9 \%$ menyatakan memperoleh informasi iari kepalasekolah/guru/administrasi, $19.6 \%$ ewat keluarga/tetangga, $9.3 \%$ menya-

kwat siswa dan $6.2 \%$ menyatakan lewat media

Sementara hanya $3.1 \%$ menyatakan kalau : us akreditasi MTS Alkharat Pusat Palu lewat sosialisasi.

Masyarakat Terhadap Madrasah Ter-

Pe»ilaian Respanden Terhadap MTS AlPusat Palu

Grfaik 5.

i rtsponden terhadap MTS Alkhairat Pusat Palu

Penilaian Responden

\section{m i l l}

\section{$S$}

a:an responden terhadap Madrasah Tsanaao Alkhairat Pusat Palu terkategorikan tinggi hal fapat dilihat pada analisis kecendrungan penilaian mi en terhadap komponen akreditasi yang berada a 3.1-4.0. Penilaian responden terhadap lias Madrasah Tsanawiyah Alkhairat Pusat Palu elakategorikan tinggi tersebut tampak pada kualitas k-ijm. proses belajar, kepala madrasah, guru, sarana ana. pengelolaan dan evaluasi. Sementara iaian responden terkategorikan cukup tinggi, yaitu fe»s tenaga administrasi dan pembiayaan.

Tingkat penilaian responden terhadap kualitas KTSP

-nan responden terhadap kualitas kurikulum Madrasah Tsanawiyah Alkhairat Pusat Palu Idkategori tinggi (rata-rata skor 3.5). Hal ini dapat iiamati dari distribusi jawaban responden terhadap :em tersebut. $96.9 \%$ menyatakan bahwa kualitas

SP cukup sempurna dan $3.1 \%$ menyatakan ndak sempurna. Adanya singkronisasi antara amran dan penerapan pada MTS Alkairat Pusat Palu. b. Tingkat penilaian responden terhadap kualitas proses pembelajaran.

Proses pembelajaran pada MTS Alkhairat Pusat Palu terkategori tinggi, (rata-rata skor 3.4), yang diterapkan di MTS Alkhairat Pusat Palu dilakukan secara konsisten. $92.8 \%$ menyatakan penilaiannya terhadap kualitas proses pembelajaran cukup konsisten, dan $7.2 \%$ menyatakan tidak konsisten. Karena alokasi jam pelajaran tidak berubah-ubah dan nilai yang didapatkan oleh siswa cukup baik.

c. Tingkat penilaian responden terhadap kualitas kepala madrasah

Terkategori tinggi (rata-rata skor 3.9). Hal ini diamati pada penilaian peryataan responden terhadap kualitas kepala madrasah MTS Alkhairat Pusat Palu saat ini. Terdapat jumlah $98 \%$ menyatakan merasa bangga dengan kualitas Kepala MTS Alkhairat Pusat Palu, dan $2 \%$ menyatakan tidak bangga terhadap kualitas kepala Madrasah Tsanawiyah Alkhairat Pusat Palu. Karena kamad-nya memiliki kepribadian dan kharisma dalam kepemimpinannya.

d. Tingkat penilaian responden terhadap kualitas guru.

Madrasah Tsanawiyah Alkhairat Pusat Palu terkategori tinggi (rata-rata skor 3.2). Hal ini menunjukkah $79.4 \%$ menyatakan ber kualitas. dan $20.6 \%$ menyatakan perlu ditingkatkan. Terhadap guru Madrasah Tsanawiyah Alkhairat Pusat Palu. Karena memiliki kompetensi personal serta layak sebagai pendidik karena sesuai disiplin ilmunya.

e. Tingkat penilaian responden terhadap kualitas tenaga administrasi

Madrasah Tsanawiyah Alkhairat Pusat Palu terkategori cukup tinggi (rata-rata skor 2.7). Terlihat dari hasil distribusi jawaban responden terhadap penilaiannya. $69 \%$ menyatakan berkualitas, dan $21 \%$ menyatakan tenaga administrasi MTS Alkhairat Pusat Palu perlu ditingkatkan. Tingkat pelayanan sangat dirasakan atau tersentuh oleh masyarakat/orang tua siswa.

f. Tingkat penilaian responden terhadap kualitas sarana dan prasarana

Pada aspek ini terkategori tinggi (rata-rata skor 3.2). Hal ini diamati pada penilaian peryataan responden terhadap kualitas sarana dan prasarana MTS Alkhairat Pusat Palu saat ini. 92.8\% menyatakan lengkap, dan $7.2 \%$ menyatakan kalau sarana dan prasarana MTS Alkhairat Pusat Palu tidak lengkap. Jumlah siswa keseluruhan 
466 semuanya masuk pagi ditambah dengan 24 siswa (kelas unggulan), ruang belajar/laboratorium serta aktivitas pembelajaran berjalan dengan baik.

g. Tingkat penilaian responden terhadap kualitas pengelolaan.

Kualitas pengelola terkategori tinggi (rata-rata skor 3.2). Tingkat tersebut dapat diamati secara jelas dari jawaban responden terhadap kualitas pengelolaan di MTS Alkhairat Pusat Palu. 95.9\% menyatakan termanajerial dan hanya $4.1 \%$ menyatakan bahwa pengelolaan Madrasah Tsanawiyah Alkhairat Pusat Palu tidak manajerial. Tenaga pendidik dan kependidikan memiliki ketiga kompetensi dalam mengimplementasikan hal tersebut.

h. Tingkat penilaian responden terhadap kualitas pembiayaan.

Kualitas pembiayaan pendidikan terkategori cukup tinggi (rata-rata skor 2.8). Tingkat tersebut dapat diamati secara jelas dari jawaban responden terhadap kualitas pembiayaan di MTS Alkhairat Pusat Palu. $74.3 \%$ menyatakan sudah cukup, dan $25.7 \%$ menyatakan perlu ditingkatkan kualitas pembiayaan di MTs Alkhairat Pusat Palu. MTs Alkhairat Pusat Palu berupaya membangun dan mewujudkan visi dan misi.

i. Tingkat reponden terhadap kualitas evaluasi.

Pada aspek ini Madrasah Tsanawiyah Alkhairat Pusat Palu terkategori tinggi (rata-rata skor 3.5). Tingkat penilaian tersebut dapat diamati secarajelas pada hasil jawaban responden terhadap item yang dimaksud. Terdapat $95.9 \%$ menyatakan obyektif, terpadu, sistematis, dan $4.1 \%$ menyatakan bahwa evaluasi pembelajaran pada MTs Alkhairat Pusat Palu tidak obyektif, terpadu, sistematis. Hanya satu konsep yang dijadikan sebagai landasan yaitu kecintaan terhadap Alkhairat dan KH. Habib Idrus Bin Salim Aldjufri yang disebut dengan sebutan "guru tua."

j. Penilaian responden terhadap kualitas lulusan.

\section{Grafik 6.}

Kulaitas lulusan MTs Alkhairat Pusat Palu

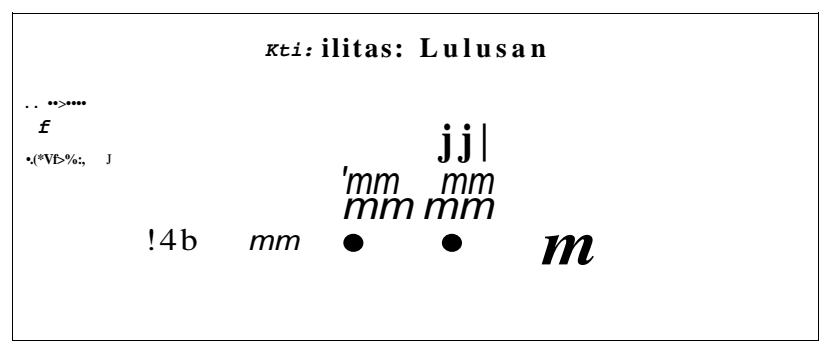

MTS Alkhairat Pusat Palu. Menurut responden bahwa kualitas lulusan Madrasah Tsanawiyah Alkhairat Pusat Palu terlihat dari hasil penilaian responden menunjukkan jumlah $95.9 \%$ menyatakan kualitas lulusan MTS Alkahirat Pusat Palu berbobot, dan $4.1 \%$ menyatakan bahwa kualitas lulusan pada Madrasah Tsanawiyah Alkhairat Pusat Palu tidak berbobot.

2. Minat Responden Berpatisipasi Terhadap MTs Alkhairat Pusat Palu.

a. Penilaian responden terhadap minat menyekolahkan anak.

Grafik 7 .

Penilaian responden terhadap minat menyekolahkan anak.

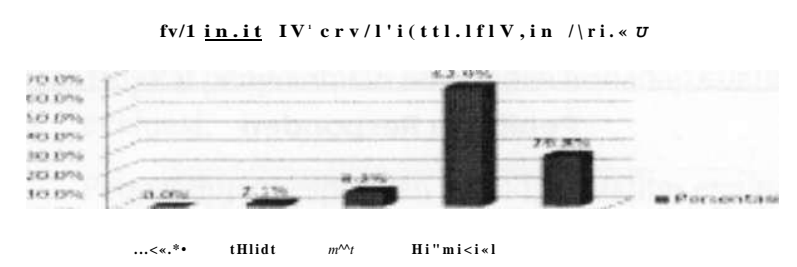

Minat responden menyekolahkan anak pada MTs Alkhairat Pusat Palu, tergambar pada jawaban responden terhadap pilihan dalam pertanyaan tersebut, yaitu $97.9 \%$ menyatakan berminat menyekolahkan anaknya pada MTs Alkhairat Pusat Palu, dan $2.1 \%$ menyatakan tidak berminat menyekolahkan anaknya pada MTs Alkhairat Pusat'Palu.

b. Memberikan saran terhadap upaya peningkatan kualitas MTs Alkhairat.

Grafik 8.

Memberikan saran terhadap upaya peningkatan kualitas MTs Alkhairat

P\&rtislpa\&i S a r a n

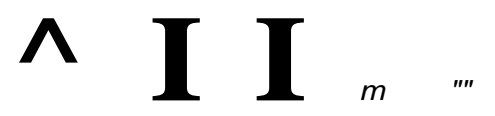

Saran terhadap peningkatan kualitas MTs Alkhairat Pusat Palu, tergambar pada jawaban responden terhadap pilihan dalam pertanyaan tersebut, yaitu $98 \%$ menyatakan berminat memberikan saran untuk kualitas MTs Alkhairat Pusat Palu, dan 2\% menyatakan kalau 
nimat memberikan saran terhadap MTs Itdfearat Pusat' Palu. Ini merupkan gambaran akan rasa •...tnya terhadap Alkhairat dan "guru tua."

Mir.at responden untuk terlibat aktif dalam -pa>a peningkatan kualitas.

Grafik 9.

* u i responden untuk terlibat aktif dalam upaya peningkatan kualitas.

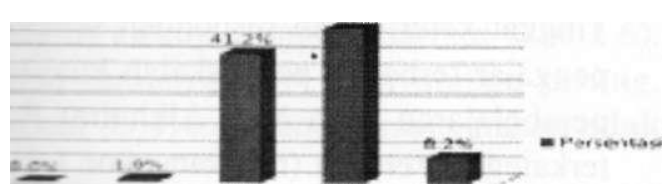

-'i-rasah Tsanawiyah Alkhairat Pusat palu ini erpmbar lewat jawaban responden bahwa yang nmrvatakan $99.9 \%$ menyatakan berminat untuk - uHul aktif dalam meningkatkan kualitas MTs Mmmmat Pusat Palu, dan hanya $1 \%$ yang menyatakan aal berminat dalam hal terelibat aktif pada MTs

•.- - -.: Pusat Palu.

pasi Keterlibatan Masyarakat Terhadap Madrasah Terakreditas

I_ Memberikan Saran Terhadap Kualitas MTS Alkhairat Pusat Palu

Grafik 10.

- " >p.i>i responden dalam memberikan saran

Mamtwrih^n Saran

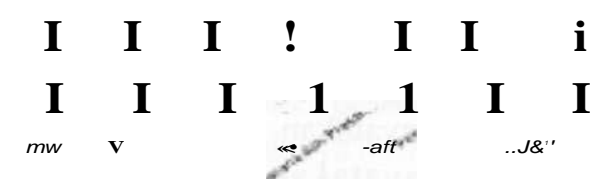

Tingkat partisipasi responden dalam bentuk ::kan saran terhadap peningkatan kualitas

- ah Tsanawiyah Alkhairat Pusat Palu tergolong caknp tinggi (rata-rata skor 2.5). Dari semua en akreditasi yang dijadikan sebagai indikator incuk mengukur tingkat partisipasi akan diurai lebih

,kat partisipasi responden dalam memberikan saran terhadap peningkatan kualitas kurikulum. MTs Alkhairat Pusat Palu terkategori cukup tinggi (rata-rata skor 2.6). Tingkat partisipasi tersebut dapat dilihat dari distribusi jawaban responden terhadap memberikan saran dalam peningkatan kualitas KTSP $73.1 \%$ menyatakan jarang, dan $26.9 \%$ menyatakan tidak pernah. Implementasi kurikulum sudah berjalan dengan baik.

b. Tingkat partisipasi responden memberikan saran terhadap peningkatan kualitas guru MTS Alkhairat Pusat Palu terkategori cukup tinggi (rata-rata skor 2.4). Tingkat partisipasi tersebut dapat dilihat dari distribusi jawaban responden terhadap memberikan saran dalam peningkatan kualitas guru $69.1 \%$ menyatakan jarang, dan $21.9 \%$ yang menyatakan tidak pernah. Kompetensi dan kredibilitas para guru MTS Alkhairat cukup baik.

c. Tingkat Partisipsai responden memberi saran terhadap peningkatan kualitas staf MTs Alkhairat Pusat Palu terkategori cukup tinggi (rata-rata skor 2.8). Tingkat partisipasi tersebut dapat dilihat dari distribusi jawaban responden terhadap memberikan saran dalam peningkatan kualitas staf. $93.2 \%$ menyatakan jarang, dan $6.8 \%$ menyatakan tidak pernah. Sudah memperlihatkan hasil yang dibangun selama ini.

d. Tingkat partisipasi responden memberikan saran terhadap peningkatan kualitas sarana dan prasarana MTs Alkhairat Pusat Palu terkategori cukup tinggi (rata-rata skor 2.7). Tingkat partisipasi tersebut dapat dilihat dari distribusi jawaban responden terhadap memberikan saran dalam peningkatan kualitas sarana dan prasarana $69 \%$ menyatakan jarang, dan $31 \%$ menyatakan tidak pernah. Proses belajar mengajar baik kelas biasa maupun kelas unggulan berjalan dengan baik.

e. Tingkat partisipasi responden dalam memberikan saran terhadap peningkatan kualitas pengelola MTs Alkhairat Pusat Palu terkategori cukup tinggi (rata-rata skor 2.5). Tingkat partisipasi tersebut dapat dilihat dari distribusi jawaban responden terhadap memberikan saran dalam peningkatan kualitas pengelola. $58.7 \%$ menyatakan jarang, dan $41.3 \%$ menyatakan tidak pernah. Implementasi pengelolaan sudah berjalan, namun perlu adanya peningkatan secara keseluruhan terhadap komponen tersebut.

f. Tingkat partisipasi responden dalam memberikan saran terhadap peningkatan evaluasi pembelajaran MTs Alkhairat Pusat Palu terkategori cukup 
tinggi (rata-rata skor 2.3). Tingkat partisipasi tersebut dapat dilihat dari distribusi jawaban responden terhadap memberikan saran dalam peningkatan evaluasi pembelajaran. $61.8 \%$ menyatakan jarang, dan $38.2 \%$ menyatakan tidak pernah. Lima tahun terakhir terlihat adanya perkembangan lewat manajemen MTs Alkhairat Pusat Palu.

\section{Keterlibatan Dalam Peningkatan Kualitas MTs Alkhairat Pusat Palu.}

Keterlibatan responden dalam peningkatan kualitas MTs Alkhairat Pusat Palu terdapat tujuh komponen yang menjadi aspek keterlibatan responden diantaranya sebagai narasumber, tenaga pengajar, mengikuti diklat, sebagai donator pebiayaan, pengelola, donator sarana dan prasarana, dan sebagai tim evaluasi. Secara umum tingkat kategori dari masing-masing aspek dapat dilihat pada grafikl 1

Grafik 11.

Keterlibatan/partispasi responden

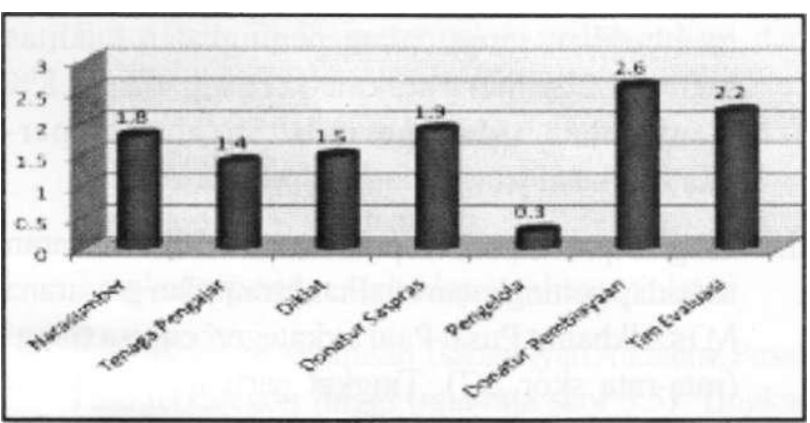

Tingkat partisipasi responden dalam behtuk keterlibatan terhadap peningkatan kualitas Madrasah Tsanawiyah Alkhairat Pusat Palu terkategori rendah. Komponen akreditasi yang dijadikan sebagai indikator untuk mengukur tingkat keterlibatan responden menunjukkan demikian, khususnya kualitas pengelolaan pada Madrasah Tsanawiyah Alkhairat Pusat Palu dalam tingkat keterlibatan sebagai narasumer terkategori sangat rendah, dan kualitas proses pembelajaran, tenaga pendidik dan kependidikan, kurikulum/KTSP, dan kualitas sarana dan prasarana terkategori rendah, sedangkan tingkat keterlibatan responden sebagai narasumber terhadap peningkatan kualitas pembiayaan dan evaluasi pembelajaran terkategori cukup tinggi.

a. Tingkat keterlibatan responden dalam sebagai narasumber.

Tingkat keterlibatan responden sebagai narasumber terhadap peningkatan kualitas
kurikulum/KTSP pada MTs Alkhairat Pusat Palu terkategori rendah (rata-rata skor 1.8). Tingkat partisipasi responden dapat lebih diamati pada distribusi jawaban terhadap opsi yang diberikan pada pertanyaan tentang itu. Terdapat $58.7 \%$ menyatakan tidak pernah, dan $41.3 \%$ yang menyatakan jarang. Masalah tersebut diserahkan sepenuhnya pada pihak MTs Alkhairat Pusat Palu.

b. Tingkat keterlibatan responden sebagai tenaga pengajar (guru)

Tingkat keterlibatan responden sebagai tenaga pengajar terhadap peningkatan kualitas proses pembelajaran pada MTs Alkhairat Pusat Palu terkategori rendah (rata-rata skor 1.4). Tingkat partisipasi responden dapat lebih diamati pada distribusi jawaban terhadap angket menggambarkan keterlibatan sebagai tenaga pengajar. Terdapat jumlah $82.5 \%$ menyatakan tidak pernah, dan $17.5 \%$ yang menyatakan jarang.

c. Tingkat keterlibatan responden dalam mengikutkan guru pada diklat-diklat. Tingkat keterlibatan responden terhadap program peningkatan kualitas tenaga pendidik dan kependidikan pada MTs Alkhairat Pusat Palu terkategori rendah (rata-rata skor 1.5). Tingkat partisipasi responden dapat lebih diamati pada distribusi jawaban terhadap program peningkatan kualitas. Terdapat $75.3 \%$ menyatakan tidak pernah, dan $24.7 \%$ yang menyatakan jarang. Diasumsikan bahwa guru MTs Alkhairat dalam hal kompetensi dan pendidikannya sudah tidak diragukan.

d. Tingkat keterlibatan responden sebagai donatur.

Tingkat keterlibatan responden sebagai donatur terhadap peningkatan kualitas sarana dan prasarana pada MTS Alkhairat Pusat Palu terkategori rendah (rata-rata skor 1.9). Terdapat jumlah $51.5 \%$ menyatakan tidak pernah, dan $48.5 \%$ yang menyatakan jarang. Tingkat penghasilan bervariasi, yang penting anak dapat bersekolah pada MTs Alkhairat Pusat Palu.

e. Tingkat keterlibatan responden sebagai pengelola madrasah.

Tingkat keterlibatan responden sebagai pengelola madrasah terhadap peningkatan kualitas pengelolaan pada MTs Alkhairat Pusat Palu terkategori sangat rendah (rata-rata skor 0.3). Tingkat partisipasi responden dapat lebih diamati pada distribusi jawaban terhadap angket meng- 
... " : : N:Ill keterlibatan selaku pengeloia " aa-asah. Terdapat jumlah $78.4 \%$ menyatakan idak pernah, dan $21.6 \%$ yang menyatakan prang. Diasumsikan pengelolaan sudah berjalan secara manajerial pada MTs Alkhairat Pusat Pahi.

akat keterelibatan responden sebagai donatur.

Tingkat keterlibatan responden sebagai donatur -" / / peningkatan kualitas pembiayaan pada -!a::a>ah Tsanawiyah Alkhairat Pusat Palu gori cukup tinggi (rata-rata skor 2.6). Terdapat jumlah $54.6 \%$ menyatakan jarang, gkan $45.4 \%$ responden menyatakan tidak peroah.

-keterlibatan responden sebagai anggota 'am evaluasi

Tingkat keterlibatan responden sebagai anggota :im evaluasi terhadap peningkatan kualitas evaluasi pembelajaran pada Madrasah Tsana-

ah Alkhairat Pusat Palu terkategori cukup " n-gi rata-rata skor 2,2). Tingkat partisipasi responden dapat lebih diamati pada distribusi jawaban terhadap angket menggambarkan keterfibatan sebagai anggota tim evaluasi. Terdapat jumlah 50,5\% menyatakan jarang, dan 49,5\%

$\boldsymbol{i}$ nenyatakan tidak pernah. Kharisma Alkhairat, ada anak yang bersekolah dan meropakan sekolah agama.

k Tingkat partisipasi responden menyekolahkan anak.

Dominan responden menyatakan tingkat partisipasi untuk menyekolahkan anaknya di MTS Alkhairat Pusat Palu. Terdapat jumlah 86,6\% oonden menyatakan Ada Anak Bersekolah, dan $13,4 \%$ yang menyatakan kalau Tidak Ada Anak. Bersekolah pada MTS Alkhairat Pusat Palu. Nampak adanya hasil atas kompetensi MTS Alkhairat khususnya terhadap siswa.

Tingkat partisipasi responden mengajak keluarga/ tetangga.

Tingkat partisipasi responden mengajak keluarga/ tetangga menyekolahkan Anak di MTs, dominan responden menyatakan tingkat partisipasi untuk mengajak keluarga/tetangga menyekolahkan anaknya di MTs Alkhairat Pusat Palu. Terdapat jumlah $83.5 \%$ menyatakan satu orang anak, dan $16.5 \%$ yang mengajak keluarga/tetangga untuk menyekolahkan anaknya pada MTs
Alkhairat Pusat Palu yaitu $16.5 \%$ kredibilitas MTs Alkhairat Pusat Palu terhadap orang tua siswa sangat baik.

j. Tingkat partisipasi mendorong menyekolahkan anak.

Tingkat partisipasi responden yang mendorong menyekolahkan anak pada MTs Alkhairat Pusat Palu. Terdapat $33.0 \%$ responden menyatakan bahwa yang mendorong untuk menyekolahkan anaknya karena madrasah telah terakreditasi, $25.8 \%$ responden menyatakan karena alasan lain, $8.2 \%$ responden menyatakan menyekolahkan anaknya karena madrasah dekat rumah, dan $10.3 \%$ responden menyatakan diajak keluarga/ tetangga. Sementara terdapat jumlah $22.7 \%$ responden menyatakan alasan menyekolahkan anaknya di Madrasah Tsanawiyah Alkhairat Pusat Palu mengikuti keinginan anak.

k. Tingkat partisipasi responden dalam pengembangan kualitas Madrasah. Pada aspek ini responden menyatakan bahwa dalam hal pengembangan kualitas MTs Alkhairat Pusat Palu, terdapat $64.9 \%$ responden menyatakan karena ada anak bersekolah pada Madrasah Tsanawiyah Alkhairat Pusat Palu, 20.4\% responden menyatakan karena diundang, $6.2 \%$ responden menyatakan karena rasa prihatin terhadap Madrasah Tsanawiyah Alkhairat Pusat Palu, sedangkan $4.1 \%$ responden menyatakan bahwa yang mendorong untuk berpartisipasi dalam pengembangan kualitas Madrasah Tsanawiyah Alkhairat Pusat Palu dikarenakan tugas pokok.

\section{PENUTUP}

\section{Kesimpulan}

1. Tingkat pengetahuan responden terhadap madrasah terakreditasi pada MTs Alkhairat Pusat Palu dari delapan komponen menunjukkan kategorikan tinggi, dengan rata-rata skor 3.1. Sedangkan tingkat pengetahuan responden terhadap status akreditasi diperoleh lewat kepala madrasah, guru, dan tenaga administrasi MTs Alkhairat Pusat Palu

2. Tingkat sikap responden terhadap delapan komponen Akreditasi menunjukkan bahwa respon masyarakat terhadap madrasah terakreditasi terkategori tinggi, dengan rata-rata skor 3.2. Sedangkan tingkat minat responden dalam hal menyekolahkan anaknya, berpartisipasi memberikan saran, dan terlibat aktif 
dalam peningkatan kualitas MTs Alkhairat Pusat Palu. Hampir seluruh indikator mendapatkan respon di atas $50 \%$ pada semua aspek.

3. Tingkat partisipasi responden terhadap madrasah terakreditasi pada MTs Alkhairat Pusat Palu dengan tiga aspek yaitu memberi saran, ikut pertemuan, dan terlibat aktif terhadap delapan komponen akreditasi menunjukkan bahwa respon masyarakat terhadap madrasah terakreditasi dikategorikan cukup tinggi. Terhadap partsisipasi responden pada MTs Alkhairat Pusat Palu, yaitu: 1) Partisipasi responden terhadap memberikan saran dengan nilai (rata-rata skor 2.5) terkategori cukup tinggi, 2) Ikut pertemuan/rapat terkategori cukup tinggi dengan nilai (rata-rata skor 2.5), dan 3) Terlibat aktif dalam peningkatan kualitas MTs Alkhairat Pusat Palu terkategori rendah dengan nilai (rata-rata skor 1.7 )

\section{Rekomendasi}

1. Diharapkan pihak MTs Alkhairat Pusat Palu dapat konsisten terhadap kualitas yang selama ini dibangun dalam pencitraan madrasah terhadap orang tua siswa dan masyarakat.

2. Peran pemerintah dalam hal ini Kementerian Agama, Kementerian Pendidikan Nasional, dan BAN S/M, dapat mengawal dan membina MTs Alkhirat Pusat Palu, sehingga minat orang tua siswa dan masyarakat dalam menyekolahkan anaknya khususnya pada madrasah.

3. Untuk meningkatkan keterlibatan partisipasi, maka pihak MTs Alkhairat Pusat Palu supaya bisa lebih meningkatkan lagi informasi dan koordinasi terhadap orang tua siswa.

\section{Ucapan Terima Kasih}

Penelitian ini dibiayai oleh DIPA Balai Penelitian dan Pengembangan Agama Makassar Tahun 2011. Ucapan terima kasih diperuntukkan kepada para informan di lapangan khususnya para responden, juga terima kasih kepada teman-teman dibidang pendidikan agama dan keagamaan pada Balai Penelitian dan Pengembangan Agama Makassar afas kebersamaan kita selama ini.

\section{DAFTAR PUSTAKA}

Badruzzaman dan Mukjizatullah. 2010. Respon Masyarakat Terhadap Madrasah Diniyah, Laporan Penelitian Balai Litbang Agama Makassar.

BAN S/M. 2009. Kebijakan dan Pedoman Akreditasi Sekolah Madrasah, Profesional.Terpercaya dan Terbuka (BAN, 2009, Jakarta).

Barokah, Slamet Umi Nur. 2005. Pengaruh Akreditasi Sekolah dan Persepsi Guru mengenai Supervisi Kepala Sekolah Terhadap Prestasi Belajar Siswa. Jurusan Pendidikan Ekonomi Akuntansi. Fakultas Ilmu Sosial UniversitasNegeriSemarang. (ttp://digilib.unnes.ac.id/gsdl/collect/skripsi/archives/ HASH5bl3.dh7doc.pdf)

Hidajati, Anik. 2009. Peran Kepala Sekolah dalam Perolehan Status Akreditasi Sekolah di SMPNegeri 4 Karanganyar. Tesis. Surakarta: Program Studi Teknologi Pendidikan, Program Pascasarjana, Universitas Sebelas Maret, Desember. 2009. ( http://pasca.uns.ac.id/?p=384)

Srihani. 2006. Analisis Dampak Akreditasi Sekolah Dalam Peningkatan Mutu Pendidikan (Studi Kasus Di SD Negeri Donohudan 3 Kecamatan Ngemplak Kabupaten Boyolali). Thesis thesis, Universitas Muhammadiyah Surakarta, 2006. (http://etd.eprints.ums.ac.id/6856/)

Raharjo, Bambang Budi. T.th. Dampak Kebijakan Akreditasi Sekolah dan Sertiflkasi Guru terhadap Peningkatan Mutu Pendidikan di Kabupaten Banyumas, Propinsi Jawa Tengah. [Experiment], http://eprints.ui.ac.id/78638/

\section{Internet}

www.hasanismailr.blogspot.com/2009/06/pengertian

http://blogwirabuana. wordpress.com/2010/01/ 05/akreditasisekolah/madrasah

http://www.infoskripsi.com/ Free-Resource/Konsep-PerilakuPengertian-Perilaku-Bentuk-Perilaku-dan-DomainPerilaku.html

Septiayuam Barsari, blogspot.com/2010/05/definisi-akreditasisekolah madrasah.html 